\title{
Dissociated Retinal Cell Culture
}

Christine Jolicoeur and Michel Cayouette*

Cellular Neurobiology, Institut de Recherches Cliniques de Montreal, Montreal, Canada *For correspondence: michel.cayouette@ircm.qc.ca

[Abstract] The retina is a relatively simple and accessible part of the central nervous system, making it a powerful model to study cell fate specification mechanisms. Multipotent retinal progenitor cells (RPCs) give rise to seven major classes of retinal cell types. Mechanisms regulating cell fate choice in the retina depend on both cell intrinsic and environmental factors, but their relative contribution to specific cell fate decisions remains unclear. Dissociated retinal cell cultures provide a great assay to study this problem. RPCs are cultured in serum-free and extract-free medium, providing the investigator with a control over the environment to address questions related to the effects of a particular molecule on the development of retinal neurons. In addition, dissociated cell cultures can be used to study the importance of cell intrinsic mechanisms by isolating RPCs from their normal environment (Cayouette et al., 2003; Jensen and Raff, 1997). The method described below is suitable for the clonal-density culture of RPCs. In such cultures, RPCs are isolated from each other and from the postmitotic neurons. They divide and differentiate into different retinal cell types to form small colonies, or "clones". In a recent study, we found that these clones are indistinguishable from the clones that develop in situ in the retina, both in terms of cell number and cell type composition, suggesting that intracellular mechanisms play a key role in retinal development (Cayouette et al., 2003).

\section{Materials and Reagents}

1. Animals

We typically use retinas from albino Sprague Dawley rats. This method works for culturing rat retinas aged between embryonic day 17 to post-natal day 1 . Younger and older retinal cells or retinal cells from mouse retinas do not seem to survive as well under these conditions, but can also be cultured.

2. DPBS (Life Technologies, catalog number: 14040)

3. Neurobasal medium (Life Technologies, catalog number: 21103-049)

4. DMEM/F12 medium (Life Technologies, catalog number: 10565-018)

5. B27 supplement (Life Technologies, catalog number: 17504-044)

6. Pen/Strep (P/S) (Life Technologies, catalog number: 15140-122)

7. Poly L-lysine (PLL) (Sigma-Aldrich, catalog number: P-4707) 
8. Mouse Laminin (Life Technologies, catalog number: 23017-015)

9. Papain (Worthington Biochemical, catalog number: LS003126)

10. L-cystein crystal (Sigma-Aldrich, catalog number: C-7352)

11. Trypsin Inhibitor (Roche Diagnostics, catalog number: 109878)

12. $0.45 \mu \mathrm{m}$ and $0.22 \mu \mathrm{m}$ filters (Fisher Scientific, catalog number: SLHV033RS and SLGP033RS)

13. Hoechst 33342 (Life Technologies, Molecular Probes ${ }^{\circledR}$, catalog number : H3570)

14. "Incomplete" RGM medium

15. Growth factors (see Recipes)

a. bFGF (Pepro Tech, catalog number: 100-18B)

b. EGF (Pepro Tech, catalog number: 315-09)

c. NT-3 (Pepro Tech, catalog number: 450-03)

d. BDNF (Pepro Tech, catalog number: 450-02)

16. 10x Lo Ovomucoid (see Recipes)

17. $20 \times 4 \%$ BSA (Sigma-Aldrich, catalog number: A-4161) (see Recipes)

18. $0.4 \%$ DNase (Worthington Biochemical, catalog number: LS002007) (see Recipes)

19. Insulin (2.5 mg/ml) (Sigma-Aldrich, catalog number: I-6634) (see Recipes)

20. cpt-cAMP (Sigma-Aldrich, catalog number: C-3912) (see Recipes)

21. N-acetyl cysteine (NAC) (Sigma-Aldrich, catalog number: A-9165) (see Recipes)

22. Forskolin (Sigma-Aldrich, catalog number: D-2438) (see Recipes)

23. N2 Supplement (see Recipes)

24. 4\% Paraformaldehyde (Electron Microscopy Science, catalog number: 15710) (see Recipes)

25. Apo-Transferrin (Sigma-Aldrich, catalog number: T-1147) (see Recipes)

26. Progesterone (Sigma-Aldrich, catalog number: P-8783) (see Recipes)

27. Putrescine (Sigma-Aldrich, catalog number: P-5780) (see Recipes)

28. Sodium Selinite (Sigma-Aldrich, catalog number: S-5261) (see Recipes)

\section{Equipment}

1. $35 \mathrm{~mm}$ petri dish (BD Biosciences, Falcon ${ }^{\circledR}$, catalog number: 353001 )

2. $50 \mathrm{ml}$ conical tube

3. $\mathrm{CO}_{2}$ incubator

4. $15 \mathrm{ml}$ conical tube

5. $100 \mathrm{~mm}$ petri dish

6. $\mathrm{CO}_{2}$ chamber

7. Straight forcep 
8. Fine forcep (Fine Science Tools, catalog number: 11252-23)

9. Curved forcep (Fine Science Tools, catalog number: 91197-00)

10. Sharp scissor

11. Laminar flow hood

12. Water bath

13. P1000 pipette

14. Microscope

15. Hemacytometer

16. Centrifuge

\section{Procedure}

Day before experiment

A. Coat culture dishes with poly-L-lysine and laminin

1. Prepare a $50 \%$ working solution of Poly L-lysine (PLL) by diluting the stock solution in sterile water. Add $1.5 \mathrm{ml}$ of PLL solution to each $35 \mathrm{~mm}$ petri dish. Leave at RT for 60 min. Remove PLL and let dry in the hood. Wash three times with sterile water.

2. Prepare the mouse laminin solution at a concentration of $5 \mu \mathrm{g} / \mathrm{ml}$ in cold Neurobasal medium. Add $1.5 \mathrm{ml}$ of mouse laminin solution to the dish.

3. Incubate for at least overnight in an incubator equilibrated at $37{ }^{\circ} \mathrm{C}$ and $8 \% \mathrm{CO}_{2} .5 \% \mathrm{CO}_{2}$ incubation is ok, but not optimal for the Neurobasal/DMEM/F12 medium mix. Longer incubation can be done and were found to improve quality of the prep.

B. Prepare the "incomplete" retina growth medium (RGM)

1. In a $50 \mathrm{ml}$ conical tube, under sterile condition, add to following:

$10 \mathrm{ml}$ of Neurobasal medium

$10 \mathrm{ml}$ of DMEM/F12 medium

$100 \mu \mathrm{l}$ of $\mathrm{N} 2$ supplement

$200 \mu \mathrm{l}$ of B27 supplement

$200 \mu \mathrm{l}$ of $100 x$ Pen/Strep (P/S)

$200 \mu \mathrm{l}$ of $6 \mathrm{mg} / \mathrm{ml} \mathrm{NAC}$

$40 \mu \mathrm{l}$ of $50 \mathrm{mM}$ cpt-cAMP

$20 \mu \mathrm{l}$ of $10 \mathrm{mM}$ Forskolin

$200 \mu \mathrm{l}$ of $2.5 \mathrm{mg} / \mathrm{ml}$ Insulin

Filter sterilize the solution using a $0.22 \mu \mathrm{m}$ filter previously rinsed with Neurobasal medium and stored at $4{ }^{\circ} \mathrm{C}$ until needed. 
Day of Experiment

A. Prepare the solution needed (see Recipes for the preparation of the stock solutions)

1. "Incomplete" RGM medium add the growth factors

$4 \mu \mathrm{l}$ of EGF $250 \mu \mathrm{g} / \mathrm{ml}$

$2 \mu \mathrm{l}$ of b-FGF $100 \mu \mathrm{g} / \mathrm{ml}$

$20 \mu \mathrm{l}$ of BDNF $50 \mu \mathrm{g} / \mathrm{ml}$

$5 \mu \mathrm{l}$ of NT-3 $100 \mu \mathrm{g} / \mathrm{ml}$

To equilibrate the medium at the right temperature and $\mathrm{pH}$, put the lid on the $50 \mathrm{ml}$ tube and unscrew $1 / 4$ of a turn. Place the tube in the incubator at $37{ }^{\circ} \mathrm{C}$ and $8 \% \mathrm{CO}_{2}$ until needed.

2. Papain solution

In a $15 \mathrm{ml}$ conical tube add the following

$10 \mathrm{ml}$ of DPBS

$5 \mu \mathrm{l}$ of $1 \mathrm{~N} \mathrm{NaOH}$

$100 \mathrm{U}$ of papain solution

$100 \mu \mathrm{l}$ of $0.4 \%$ DNase

$2 \mathrm{mg}$ of L-cystein crystal (to be added only prior to using the solution for dissociation)

Keep at $37^{\circ} \mathrm{C}$ in a water bath

3. LO-OVO solution

$9 \mathrm{ml}$ of DPBS

$1 \mathrm{ml}$ of $10 x$ LO-OVO

$100 \mu \mathrm{l}$ of $0.4 \%$ DNase

Keep at $37^{\circ} \mathrm{C}$ in a water bath

B. Culture procedure

Note: The dissection should be carried out under sterile conditions. Spray the working area with $70 \%$ ethanol and use a flame. Sterilize all the instruments before use.

Prepare two $100 \mathrm{~mm}$ dish filled with $10 \mathrm{ml}$ of sterile DPBS, one to transfer the heads and the other to dissect the eyes and two $35 \mathrm{~mm}$ dish filled with $2 \mathrm{ml}$ of sterile DPBS to collect the retinas.

1. Collection of the embryos

a. Euthanize the animal in $\mathrm{a} \mathrm{CO}_{2}$ chamber.

b. Place the animal on it's back and clean the belly skin with $70 \%$ ethanol.

c. Pinch the skin with a straight forcep, lift the skin and muscle and make a $V$ shape opening using scissors on both side of the abdomen starting from the lower abdomen and cutting all the way to the side of the animal. Lift the skin and muscle upward to reveal the internal organs and uterus. 
d. Cut out the uterus and transfer it to a $150 \mathrm{~mm}$ dish.

e. Remove the embryos from the uterus and decapitate the heads with sharp scissors.

f. Transfer the heads to a $100 \mathrm{~mm}$ dish filled with DPBS.

2. Dissection of the retinas

a. Carefully remove the skin that covers the eye.

b. Place a curved forcep of both side of the eye and apply a gentle pressure. The eye should pup out.

c. Pinch the back of the eye and pull.

d. Transfer the eye in a $100 \mathrm{~mm}$ dish filled with DPBS.

i. With the lens facing downward, secure the eye in position with a fine forceps and remove the optic nerve (Figure 1, steps 1-2).
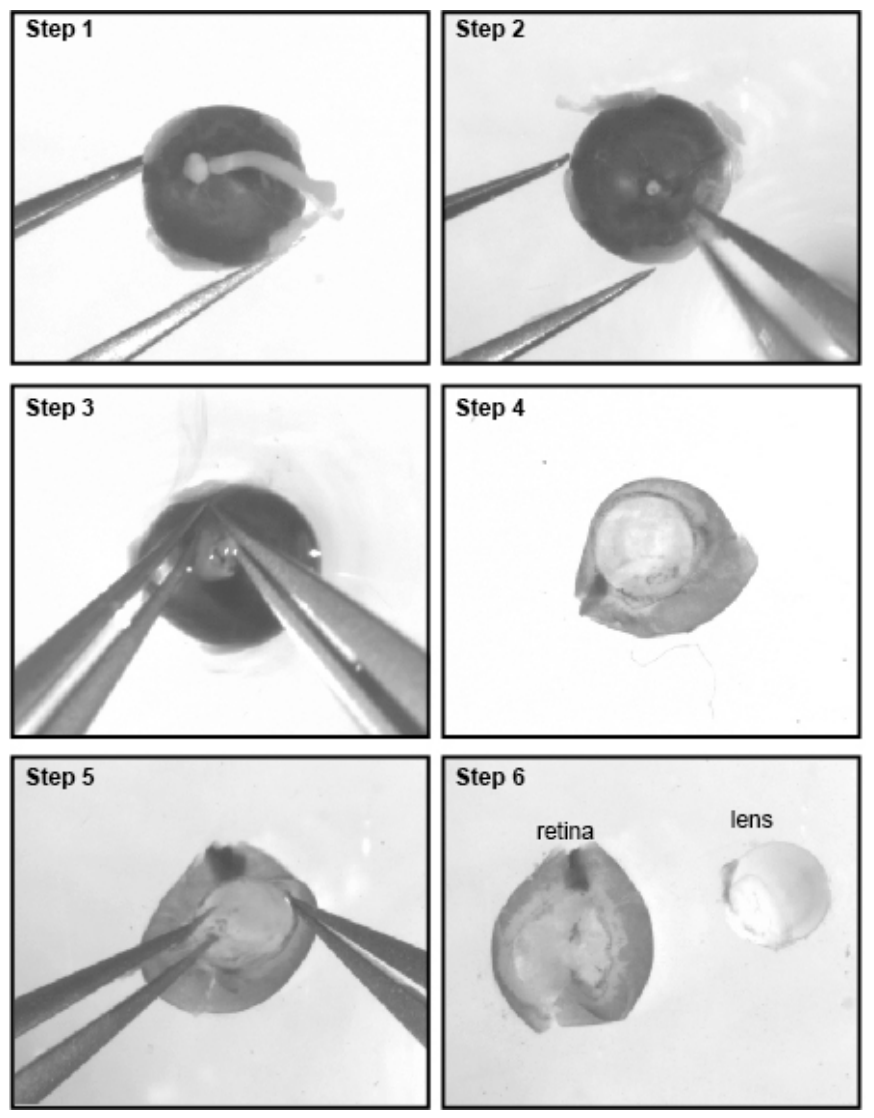

Figure 1. Dissection of the retina. Steps 1 to 5 show the procedure to dissect the retina from the eyeball. Step 6 shows the dissected retina and lens.

ii. Introduce the tip of another forceps through the optic nerve head and between the choroid and retina to secure the sclera. 
iii. Now that the sclera is secured, you need to gently tear it open with both forceps from the optic nerve head to the cornea to expose the retina and lens (Figure 1, steps 3-4).

iv. Carefully detach the lens and place the retinas in a $35 \mathrm{~mm}$ dish filled with DPBS (Figure 1, steps 5-6). From E18-19 onward, it is required to remove the blood vessel covering the retina to avoid endothelial cell contamination in the culture.

v. The blood vessels form a reddish membrane overlying the inner face of the retina. The membrane is easily removed by pinching and pulling with a fine forceps.

vi. Transfer the retinas in a $35 \mathrm{~mm}$ dish filled with DPBS. Using a fine scalpel, slice the retinas in small pieces $(2 \mathrm{~mm})$ to help the dissociation. The number of retinas to dissect depends on your need. Typically, the yield is about $0.5 \times 10^{6}$ cells for one E17 retina and $1.6 \times 10^{6}$ cells for one P0 retina. It is optimal to dissect at least 6 to 8 retina as it improve cell recovery.

3. Dissociation of the retinas (all these steps are done in the laminar flow hood)

a. Digestion of the tissue

Take out the papain tube from the water bath and add $2 \mathrm{mg}$ of L-cystein.

Transfer the pieces of retina in this tube.

Return the tube in the $37^{\circ} \mathrm{C}$ water bath and incubate $5 \mathrm{~min}$ if you are working with E17 retinas or 8 min if you are working with P0 retinas.

b. Neutralisation of the enzyme activity

Take out the tube from the water bath, let the pieces of retina settle in the bottom of the tube and remove the supernatant with gentle aspiration.

Slowly add $4 \mathrm{ml}$ of LO-OVO solution over the pieces of retina.

Let the pieces of retina settle in the bottom of the tube and remove the supernatant with gentle aspiration. Add $1 \mathrm{ml}$ of LO-OVO solution.

c. Trituration

Using the P1000, gently triturate up and down the pieces of retina to break them apart until the solution appears cloudy.

Make sure that the cell suspension is well dissociated and that no clumps of cells remain by observing a small aliquot of the suspension under the microscope.

If clumping is observed, triturate the suspension with a little more force until unicellular suspension is obtained (if the cells are difficult to dissociate, the incubation time in papain can be increased). Be careful not to over triturate the cells, this could lead to decreased survival.

Add the remaining $5 \mathrm{ml}$ of LO-OVO solution to the cell suspension and centrifuge 11 min in a benchtop centrifuge at $200 \times g$ at room temperature. 
4. Plating

a. Take out the RGM medium from the incubator.

b. Aspirate the supernatant and gently resuspend the cell pellet in $1 \mathrm{ml}$ of equilibrated RGM medium.

c. Using the hemacytometer, count the number of total cells. For clonal density culture, add 5,000 cells per $35 \mathrm{~mm}$ dish, for low density culture, add 20,000 cells per $35 \mathrm{~mm}$ dish and for high density culture, add 100,000 cells per $35 \mathrm{~mm}$ dish.

d. Dilute to right amount of cells in $1 \mathrm{ml}$ of RGM medium and add it to the $35 \mathrm{~mm}$ dish.

e. Place in the incubator at $37^{\circ} \mathrm{C}$ with $8 \% \mathrm{CO}_{2}$ for $2 \mathrm{~h}$.

f. Once the cells have adhered to the bottom of the dish, gently add another $1.5 \mathrm{ml}$ of medium and replace in the incubator.

\section{Feeding}

Feed the cells every 3 to 4 days by removing 50\% of the culture medium and adding the same amount of equilibrated RGM medium. In optimal conditions, the cells can be cultured for 10 to 14 days.

C. Immunostaining of cultured cells

Note: In these culture conditions, retinal progenitor cells will divide and differentiate into the different retinal cell types, normally produced from E17 (amacrines, bipolars, rod photoreceptors, and Müller cells). Various cell-specific markers can be used to identify the different retinal cell types. Nestin for retinal progenitor cells, Brn3b and neurofilamment 165 for ganglion cells, Rhodopsin and recoverin for rod photoreceptors, Islet-1 for bipolar cells and a subtype of amacrines and ganglion cells, whereas Pax-6 is a marker of retinal progenitor cells, amacrines and ganglion cells. Here, we provide a general protocol for immunostaining.

1. Aspirate the culture medium and fix the cells by adding cold $4 \%$ PFA for 15 min on ice.

2. Rinse three times with $1 x$ PBS.

3. Block/permeabilize for $1 \mathrm{~h}$ at room temperature (RT) with block/permeabilization solution (20\% goat serum $+0.4 \%$ Triton in $1 \times$ PBS) .

4. Prepare the primary antibody in $1 \mathrm{ml}$ of block/permeabilization solution. Dilution to be used depend on the antibody.

5. Incubate overnight at $4{ }^{\circ} \mathrm{C}$.

6. Discard primary antibody.

7. Rinse three times with $1 x$ PBS.

8. Prepare the secondary antibody in $1 \mathrm{ml}$ of block/permeabilization solution. The secondary antibody is usually used at a 1:1,000 dilution.

9. Incubate $1 \mathrm{~h}$ at RT. 
10. Discard secondary antibody.

11. Rinse three times with $1 \times$ PBS.

12. To counterstain the nucleus, incubate in Hoechst solution (1 I of Hoechst in $10 \mathrm{ml}$ of $1 \mathrm{x}$ PBS) for $5 \mathrm{~min}$ at RT.

13. Observe under inverted microscope.
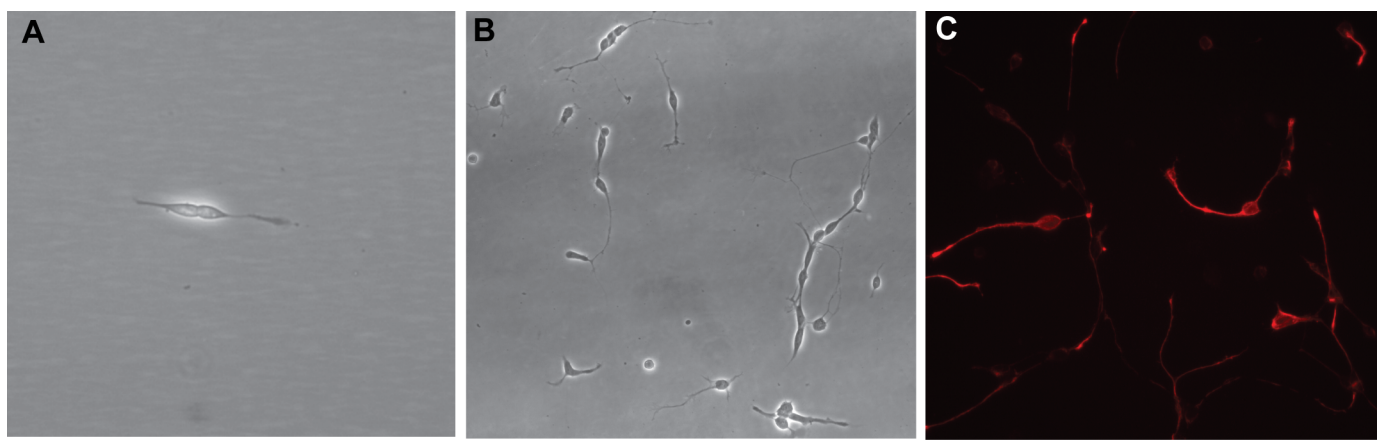

Figure 2. Phase contrast and immunostaining micrographs of dissociated cultures.

A. Two retinal progenitor cells $18 \mathrm{~h}$ after plating. Retinal progenitors have a typical bipolar morphology. B. A dissociated retinal cell culture seen after 7 days in culture showing many differentiated neurons. C. Retinal progenitor cells stained for Nestin (red) $24 \mathrm{~h}$ after plating.

\section{$\underline{\text { Recipes }}$}

1. Growth factors

a. b-FGF: Reconstitute in $10 \mathrm{mM}$ Tris pH 8.5 to a concentration of $100 \mu \mathrm{g} / \mathrm{ml}$

b. EGF: Reconstitute in water to a concentration of $250 \mu \mathrm{g} / \mathrm{ml}$

c. NT-3: Reconstitute in water to a concentration of $100 \mu \mathrm{g} / \mathrm{ml}$

d. BDNF: Dilute $1 \mathrm{mg} / \mathrm{ml}$ stock solution to a concentration of $50 \mu \mathrm{g} / \mathrm{ml}$ in water

2. 10x Lo Ovomucoid

To $40 \mathrm{ml}$ DPBS add $600 \mathrm{mg}$ BSA, Mix well

Add $600 \mathrm{mg}$ Trypsin inhibitor and mix to dissolve

Adjust $\mathrm{pH}$ to 7.4; requires the addition of approx. $400 \mu \mathrm{l}$ of $1 \mathrm{~N} \mathrm{NaOH}$

When completely dissolved, filter through a $0.22 \mu \mathrm{m}$ filter pre-rinsed with PBS

Make $1.0 \mathrm{ml}$ aliquots and store at $-20^{\circ} \mathrm{C}$

3. $20 \times 4 \%$ BSA

Add $2 \mathrm{~g}$ BSA in $50 \mathrm{ml}$ DPBS

Dissolve at $37^{\circ} \mathrm{C}$. Adjust pH to 7.4 (with approximately $200 \mu \mathrm{l} N \mathrm{NaOH}$ )

Filter sequentially through $0.45 \mu \mathrm{m}$ and $0.22 \mu \mathrm{m}$ filters, pre-rinsed with PBS

Make $1.0 \mathrm{ml}$ aliquots 
Stored at $-20^{\circ} \mathrm{C}$

4. $0.4 \%$ DNase

Dissolve $40 \mathrm{mg}$ in $10 \mathrm{ml}$ of sterile water

Mix by gentle inversion

Aliquots in $200 \mu \mathrm{l}$ and stored at $-20^{\circ} \mathrm{C}$

5. Insulin $(2.5 \mathrm{mg} / \mathrm{ml})$

To $10 \mathrm{ml}$ sterile water add

$25 \mathrm{mg}$ insulin

$50 \mu 1.0 \mathrm{~N} \mathrm{HCl}$

Mix well

Stored at $4{ }^{\circ} \mathrm{C}$ for no more than 4 to 6 weeks

6. cpt-cAMP $(50 \mathrm{mM})$

Dissolve the cpt-cAMP in sterile water at $25 \mathrm{mg} / \mathrm{ml}$

Aliquots in $200 \mu \mathrm{l}$ and stored at $-20^{\circ} \mathrm{C}$

7. $\mathrm{NAC}(6 \mathrm{mg} / \mathrm{ml})$

Dissolve $6 \mathrm{mg} \mathrm{N}$-acetyl cysteine in $1 \mathrm{ml}$ of Neurobasal medium

Aliquots in $200 \mu \mathrm{l}$

Stored at $-20{ }^{\circ} \mathrm{C}$

8. Forskolin (10 $\mathrm{mM})$

Add $2.4 \mathrm{ml}$ DMSO to a $10 \mathrm{mg}$ bottle $(4.2 \mathrm{mg} / \mathrm{ml}$ or $10 \mathrm{mM})$

Make $50 \mu \mathrm{l}$ aliquots

Stored $-20^{\circ} \mathrm{C}$

9. N2 Supplement

a. Prepare N2 stock solutions

i. Apo-Transferrin: Dissolve $500 \mathrm{mg}$ in $5 \mathrm{ml}$ of water (100 mg/ml stock solution), filter $(0.22 \mu \mathrm{M})$, aliquot and stored at $-20^{\circ} \mathrm{C}$.

ii. Progesterone: Dissolve $6 \mathrm{mg}$ in $10 \mathrm{ml}$ of ethanol to make $0.6 \mathrm{mg} / \mathrm{ml}$ stock solution, filter $(0.22 \mu \mathrm{M})$, aliquot and stored at $-20^{\circ} \mathrm{C}$.

iii. Putrescine: Dissolve $1.6 \mathrm{~g}$ in $10 \mathrm{ml}$ of water to make $1 \mathrm{M}(160 \mathrm{mg} / \mathrm{ml})$ stock solution, filter $(0.22 \mu \mathrm{M})$, aliquot and stored at $-20{ }^{\circ} \mathrm{C}$.

iv. Sodium Selenite: Dissolve $2.59 \mathrm{mg}$ in $5 \mathrm{ml}$ of water to make $3 \mathrm{mM}$ stock solution, filter $(0.22 \mu \mathrm{M})$, aliquot and stored at $-20^{\circ} \mathrm{C}$.

v. BSA: Dissolve $500 \mathrm{mg}$ in $10 \mathrm{ml}$ of water to make $50 \mathrm{mg} / \mathrm{ml}$ stock solution, filter $(0.22 \mu \mathrm{M})$, aliquot and stored at $-20^{\circ} \mathrm{C}$.

b. Prepare $10 \mathrm{ml}$ of $100 \times \mathrm{N} 2$ solution

To $7.857 \mathrm{ml}$ of DMEM-F12, add the following:

$1 \mathrm{ml}$ of Apo-Transferrin $100 \mathrm{mg} / \mathrm{ml}$ 
$33 \mu \mathrm{l}$ of progesterone $0.6 \mathrm{mg} / \mathrm{ml}$

$100 \mu$ of putrescine $1 \mathrm{M}$

$10 \mu \mathrm{l}$ of sodium selenite $3 \mathrm{mM}$

$1 \mathrm{ml}$ of BSA $50 \mathrm{mg} / \mathrm{ml}$

Aliquot in $200 \mu \mathrm{l}$ and stored at $-20^{\circ} \mathrm{C}$

10. 4\% Paraformaldehyde

Dilute a vial of $16 \%$ PFA (10 ml) in $26 \mathrm{ml}$ of water $+4 \mathrm{ml}$ of $10 x$ PBS; This solution can be kept at $4{ }^{\circ} \mathrm{C}$ for no longer than 1 month.

\section{Acknowledgments}

Funding for this work was provided by the Canadian Institutes of Health Research and the Foundation Fighting Blindness Canada. This protocol was adapted from procedures published in Cayouette et al. (2003). The authors wish to thank members of the Cayouette lab, past and present, for continuous support and improvements on the protocol over the years.

\section{$\underline{\text { References }}$}

1. Cayouette, M., Barres, B. A. and Raff, M. (2003). Importance of intrinsic mechanisms in cell fate decisions in the developing rat retina. Neuron 40(5): 897-904.

2. Jensen, A. M. and Raff, M. C. (1997). Continuous observation of multipotential retinal progenitor cells in clonal density culture. Dev Biol 188(2): 267-279. 